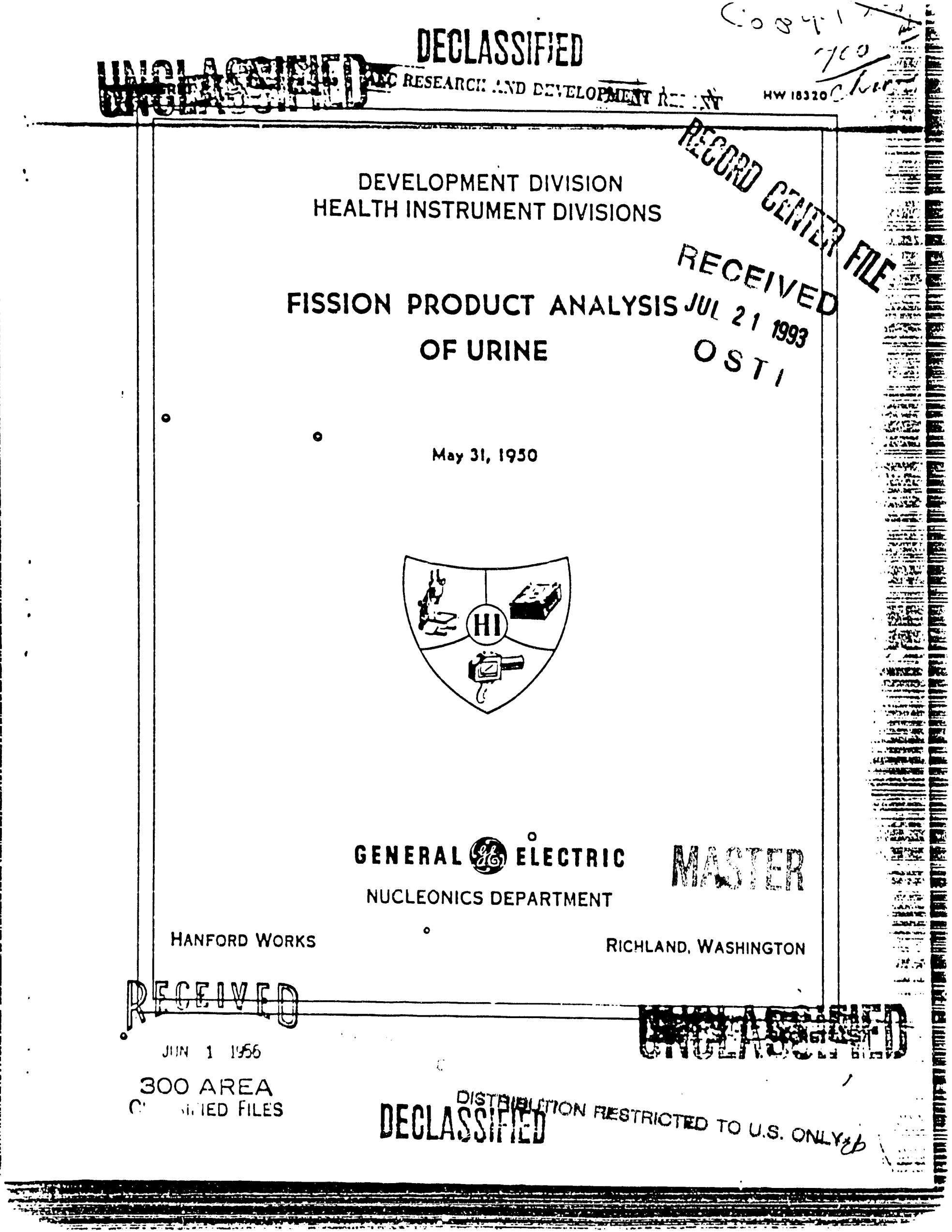




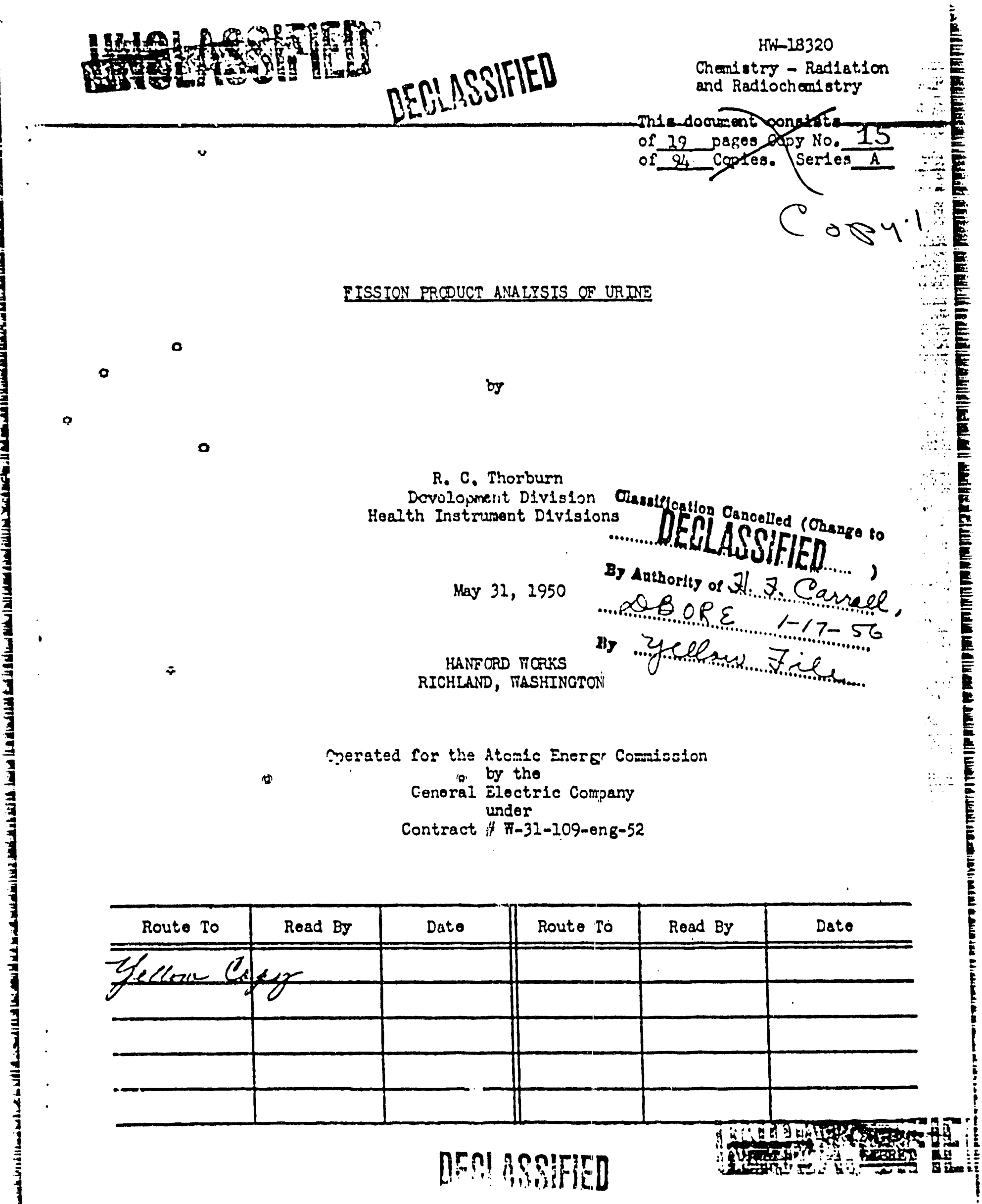


1

2

3

4

5
H. M. Parker

A. B. Groninger

C. C. Camortsfoldor

F. Albaugh

K. Schmidt - 300

$\approx$

C. M. Pattorson-W. A. McAdams-A. R. Keone

H. A. Kormberg-R. F. Fostur

Z. Z. Caroy

H. J. Pars

D. L. Ro1d

T. Singlevich

R. C. Thorbum

J. T. Hcaly

Pink Copy

Yellow Copy

7005110

Patent Group - Ch1eago 
COPY NUMBER

$18-23$

24

$25-26$

27

$28-31$

$32-33$

$34-35$

36

37

$\circ$

\section{EXTERNAL DISTRIBUTION}

Argonne National Laboratory

Armed Forcos Spec1al Weapons Project Atomlc Energy Comision, Washington Battello Memorial Inst1tute Brookhaven National Laboratory Carbide and Carbon Chenicals Division (K-25 Plant) Carbide and Carbon Chemicals Divlsion ( $Y-12$ Plant) Columbla University (Failla)

Hanford Operations Osficc

Idaho Operations offlce

Iowa State College

Kellax Corporation

Knolls Atomle Power Laboratory

Los Alamos

Mound Laboratory

National Advisory Comittee for Aeronautics

National Bureeu of Standards

Naval Modical Research Institute

Naval Radlologlcal Defense Laboratory

NEPA Project

Now Brunswlck Laboratory

ivew lork Operations office

North Amerlcan Aviation, Inc.

Oak Ridgo Nat Lonal Laboratory

Fatont Brarch, hashirigton

Techn1cal Information D1v181on, ORE

UCLA Modical Hosoarch Laboratory (Warron)

University of Calffornia Radiation Laboratory

University of Rochoster

Western Resorve Univeraity (Friedell)

Westinghouse Electric Corporation 


\section{EISSION PIIDUUCT ANAIYSIS OF URDNE}

\section{IITRODUCTION:}

\%

A chamical procedure for the englyal s of the figsion products, $\mathrm{s}^{89}, \mathrm{sr}^{89}-\mathrm{y}^{90}$ Ru106 - Rh106, Cs 137 and the long-l1ved rare earths 1.C. Ce144 - Prl4h, in urine 1s requirod for health monltoring. The present flssion product analygis for uring in routine use on all samples at hanford is lnown to give losses of Ru, Sr, and $\mathrm{C}_{s}(\mathrm{l})$. The Ru is lost in the muffling procedure but it ras hoped that the strontium and sestum could be separated and measured.

It was desired that these elements be separated togother from the bulk of the urine salts for one measurement. In addition it was dosired that a procodure be obtalned which rould allon the use of the same sample that is used for plutonium determination. Thus 1 ras necessary to copo nith the supemate from a lanthamm fluoride precipltation and the eluminum nitrate solution remalning after a TTA oxtraction. The sinal procedure was required to be simple so that up to 500 samples per month could be processed with a minlmum of manporer and equipment.

The results of this lnvestigation are presented horein.

\section{SURMARY:}

A method has ben adapted from lan exchenge etudles for romorel of the ficston products, Cs-137, Sr-90, and the rare earthe for both untroated urino samples and the supernates from the preclpitation steps in the TIA procedure for plutonium.

Because of the excessive amount of eluant necessary to separate the sission products and the resulting time required to mo segaration, a method was doveloped to removo the Sr-I, Ce and Pr by chemlcas. means and Cs from the raffinata of this extraction by $10 \bar{s}$ exchange. It should be noted that $C_{0}$ is ons1ly soparatod from pu In tho separations plant, and that 1ts presenco as a contaminato in tho outer areas 1s not as probable as tho othor long-lived fission products. This fact has boen born out In 3 yours of andyzing contaminated amplos from tho 200 Arou by the K.I. Developront D171810ne. 


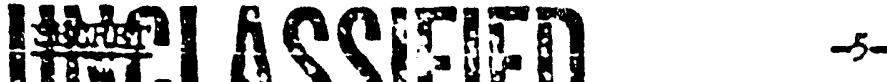 \\ Detalled procedures are presented.}

\section{Exporimental:}

All Lon colums were made from Elass tubing $7 \mathrm{~cm}$ in diamcter $\times 25 \mathrm{~cm}$ long, plugeed at the bottom with o one hole rubtor stopper, a glass tube and a pinch clamp controi for flow raies. The resin bsis nere of Dowex-50 (Nalc1te), 100 to 150 mesh, approximatels 10 deep supported on $1 / 2^{n}$ of Elass mool. Feed into tive colum was accomplished throug one I1ter separatory funnels. These funnels mereg in turn, fed from a three gallon jug durlog elution. F1g. I is a diagram of the apperatus.

All urlne samples were collected from personnel in the H.I. Levelopment Laboratorles. About $200 \mathrm{ml}$ of concontrated nitric ac1d and varying amounts of the selected flssion product were added to $1500 \mathrm{ml}$ allquots of the urine samples and these allquots ovaporated to dryness. The samples wero then ofther wet-ashod or muffled to remore organle residuen and the remaining salts dissolvod in $50 \mathrm{ml}$ of $2 \mathrm{~N}^{\mathrm{NNO}} 3 \mathrm{Fl}_{\text {th }}$ heating. This solution ras used as a starting solution for the throe types of aralyses attempted.

It should bo noted at this point, that a residue remainod after digestion of these salts. No setirity nas obscrod on this insoiubio resicue arter carerul centrifugation, rashirg and cointing.

The solubilized urine salts were then treated as dictated by experinent: (I) removal of the fission products from the raffinate of the TTA extraction with ion exchange colums (2) removal of the fission products from untreated salts with fon exchange colums and (3) removal of tino flasion products from the rafinate of the TTA extraction by chemlcal sefarations except in tho caso of Cs wich was recovered with lon exchango columa.

The afore mentioned TTA procedure is used at Hanford ports in urinalysis for plutonlum dotection. The procedure involves the separation of plutonium from the bulk of the urine salts (prepared by evaporation $\mathrm{rlth} \mathrm{FNO}_{3}$ and a subsoquent murfling at $500^{\circ} \mathrm{C}$ for one-half hour) with a fluoride precipitation of the Pu using 
plutonlu fluoride precipltate is diesolved

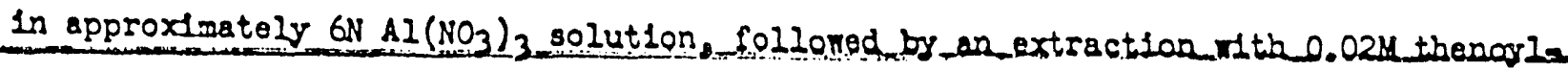
trifluoroacetone solution in benzene. After washing the organic phase with water, the plutonium is extracted from the TTA w1th a emell volume of EM HNO to dryness on a counting plate, flamed and counted to determine the amount of pu present. As may be seen from this brief outline, Pu is separated from the urine salts and contaminating long-lived fission products are soparated at one of tro places. Cs, some $\mathrm{Sr}$ and Ru, if present, would be removed at the LaF 3 precipitation whlle the rare earths and some Sr mould be carrled through tris step and would be separated at the TTA extraction step. Th1s leares two distinct types of raffinate for analysis, one consisting of a hydrofluorte ecld solution of the urino salts and the other consisting of an aluminum nitrate solution with traces of the urine salts.

In attempts to remore the fisalon groducts from the raffinate of the TTA ex"traction ithe urine solution under test ras coolas, carriers were aried and the solution treated as in the normal ITA procedure; reduction with hydroxilanine-hydrochloride, precipltation nith $\mathrm{LaF}_{3}$, solution in aluminum nitrate and finally ITA extraction. (2) The supernate from the $\mathrm{LaF}_{3}$ precipitation was evaporated to dryness, heated to removed $\mathrm{Nin}_{3}$ and finally treated with $\mathrm{H}_{2} \mathrm{SO}_{4}$ to ronove tize fluoride

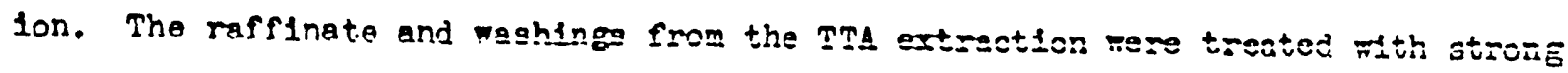
caustic to remove the aluminum as soiublo aluminate and the rare earths then preclpitated as hydroxides. Oxalate Ion was also added to precipitate any strontium that carried over as soluble strontlum salts. The supernate was discurd and the resulting hydroxide plus oxalate precipitate was dissolved in a minimum amount of $2 \mathrm{~N}$ $\mathrm{HNO}_{3}$, brought to dryness to destroy the oxalate 1on, and the salts then dissolved In $0.25 \mathrm{HNO}_{3}$. This solution ras combined with the residue from the Lar 3 precipitation. The comblnod salt solution mas diluted to approximately $100 \mathrm{mls}$. With $0.25 \mathrm{~N}$ $\mathrm{HNO}_{3}$ and used as the foed solution for the colums.

In attcrpts to romovo tho flsolun products from untroated urino salts, a solu- 
tion $0.25 \mathrm{~N}$ in $\mathrm{HNO}_{3}$ was made from tho $2 \mathrm{~N} \mathrm{HNO}_{3}$ solution of mufficd salts. This solu-

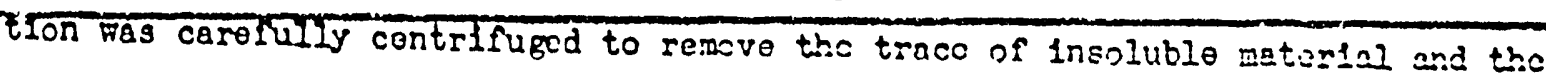
supernate used as feed. Tho preclpitato ras rounted for counting, and as proviouslo mentloned, contalnod no actirity.

In attumpts to removo the $118 s 10 n$ products, Ce-Pr, and $S r-Y$ chomlcally, followed by $\mathrm{Cs}_{s}$ extraction with ion colurins, the solution of murfled salts rias put through the rogular TTA procedure. The raffinate from the oxtraction steps ras analyzed 71 th the curront procedure in use bo the Hanford Bloassay Group for flssion products. No attempt is made to analyzo the raffinate from the Lar 3 precipitation for f1s810n products currently and the losses notod below have been found to occur at this step. Experlence with this procedure has shown good rocoverios for the rare earths, approximately $40 \%$ rocovery for Sr and no recovery for Cs. The supcrnato from the LaT3 precipltate was analyzod for Sr. After Sr rocovery it ras analyzed for $\mathrm{Cs}_{3}$ by evaporation of the raffinate to dryness, hoating to remore $\mathrm{MI}_{3}$, and flnalIs solution of the salts with $0.25 \mathrm{NNO}_{3}$ for feed into the columns.

Two different types of enalyses wero used to recover $2 r$. The first trials were run by evaporation of the $\mathrm{LaF}_{3}$ supernate to near dryness, and separation of the alkaline earths with fumlng nitric acid followed by a $\mathrm{SO}_{4}=$ preclpitation in acid. The strontium sulfato precipitate was washed, dried, and counted. Ylelds were low for this procodure. Hore successiul attempts were mu by neutralizing the LaF 3 supornate to a $\mathrm{pH}$ of 2 , adding excess sulfate $10 \mathrm{n}$, jeating at $90^{\circ} \mathrm{C}$ for $30 \mathrm{mins}$., centrifuging, weshing, drying and counting the precipitate.

Colum conditions and characteristics were beged on provious rork ${ }^{(3)}$. Flow rate was approximatoly $1 \mathrm{cc} / \mathrm{m} 1 \mathrm{n} / \mathrm{cm}^{2}$ of regin bed. Tho food solutions rere $0110.25 \mathrm{~N}$ In $\mathrm{HNO}_{3}$. Elutant acld1ty was $0.25 \mathrm{~N}$ unt1l all the snlts pore rashed out, and thon changed to $2 \mathrm{~N} \mathrm{HNO}_{3}$ to romove the slsslon products and finally to $\mathrm{LN} \mathrm{KHO}_{3}$. It ras found that $2 \mathrm{~N}$ acld $\mathrm{F} 1 \mathrm{ll}$ remove $\mathrm{Cs}, \mathrm{Sr}$, and $\mathrm{Y}$ from the resin but that $\mathrm{HI} \mathrm{HNO}_{3}$ is

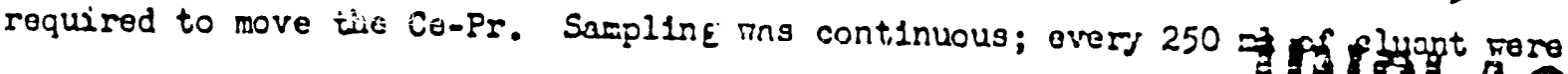


All counting ras done on tha flrst shalf of a stunciard thin mica end rindow counter. By counting all somples with the same geometry on the same type of mount, backscatter corrections, window and air absorption corroctions, and goometry corrections could be ignored in obtaining rolative values. Co was counted with its daughter; Sr measurements included the $Y$ daughter unloss spec1f1celly mentionod. Results:

The sampling results were plotted as counts/min vs volume and as reight $v$ s volume. In this manner the separation of the bulk of salts from the fission products could be readily discerned.

F1gure II is a plot of the separation obtalned on the raffinate from tho TTA extraction. Three runs are plotted; ono shoring a Cs soparation from urino salts, ono shoring a Sr separation and ono showine tho separation of Co. It is believed that tho $Y^{90}$ band did not show during the Sr anslysis bucauso of a oigit dey lag in counting after the annlysis.

Recovery in ail these runs approached 100\%.

F1 guro III is a plot of the Sr separation from untroated uriro salts. Agair good separations wero obtained. The coluran was stopped over the weekend after 24.5 I1ters had gone through and then rosumed. Counting ras done the Mednosday followIne the stopovor allowing conslderable decay of $Y^{90}$. It is interesting to noto tho excollent separation obtalned betioen the fission products oven rithout the use of comploxing agents.

Tho chemical rocovories of the fisolon products by the current bota process in the Bloaseay laboratorles has shown sood rucoveries for the rare varths: approximately 100\% for Co and approximately 85\% for Y. Strontium recover, holzever, has boen only around $40 \%$ and $\mathrm{Co}$ rocovory nil. Analysis of $\mathrm{LaF}_{3}$ supermate for strontium by ovaporation, Sr precipitation with fumine nitrio acld followod by a $\mathrm{SO}_{4}$ " procipi-

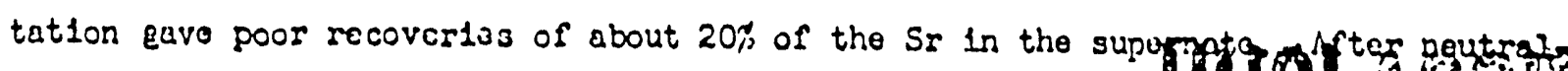




\section{HWLASTIIID

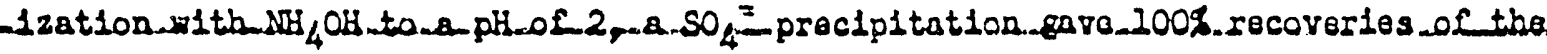

Sr in the supernato. It should bo noted that a four day delay was alloned after the analysis bofore countine. Th1s allowod the $y^{90}$ to butld lip to transient equellbrium thus allowing a direct comperison to tho counting rate of the original splke. All spike standardization was done by counting theso beta omitters with 20 mg of the rospective cerriors. A consideratie variation in counting rate due to unovun spread without carriers ras found in provious work.

The Cs recovory from the Sr supernate with fon colums approached 100 is and was ginilar in spoaration characteristics to that shown in F1gure 2.

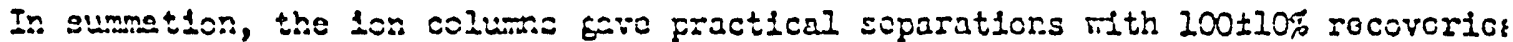
of the fission products and a roduction of solid content to less than 200 mgs. A rapld, oimple analysis for Sr in urine salts has also boon doveloped.

\section{Discuse10n:}

As may be seen by Figures 2 and "3, seperstion by elution only, requires a large volumo of eluant which requires timo. At a flow rato of 30 to $40 \mathrm{ml} / \mathrm{min}$ approxlmately 12 hours would be requirod for elution. In addition, considerable time and equipment would be required for ovaporation bofore counting, further compllcating the procedure. For these reason, the rother rapid and stiplo chcostcal soperation was developed for the complete separation of the rare, earths and $\mathrm{Sr}$. $\mathrm{Cs}$ can then be recovered from the raffinate with ion colums if desired. In throe years of analyzing some 300 samples of contamination from Hanford Works only tro samples showed a Cs content of over $50 \%$ of the totel activity. Theso samplos vero from the R-3 area (broken wagte line) and sub-surfacc soll samplog from the geolog invest1gat1ons. In no case has $\mathrm{Cs}$ evon been the only contaminant but has alriajs beon assoclated with ofthor $\mathrm{Sr}^{90}$ or $\mathrm{Ce}^{141}$.

No attempt was mado to develop spocific analytical determinations for oach flseion product. However after separations for total flssion products havo beon mado as outlined horeln further soparations cou's bo oaslly mado with standard

lo attempt was mado to devolop apod 


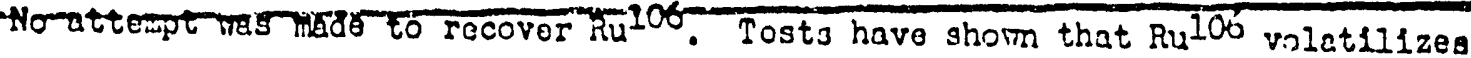

from urine salts during muffling. Special samples will be required for Rulob analysis mici could be adapted from the standard F.P. procedures using large equipnent. The three procodures are sutlined in the appendix. 


\section{WHLASSIIIER}

(1). Healy, J. Ti. Froject Document iñi-10522 Bloasgay at Hanford 7-20-48.

(2). Parker, H. M. Project Docunent \#7-4664 Manunl of Standard Procodures Bloassay (Spoctal Studieg) 5-1-46.

(3). Thorburn, R. C. Projoct Document HW-15742 The Separation of Pad10nctive Cs from Hacro Quant1tios of Sodium and Potassium Selts. 1-27-50 
Ion column procedure for analysis of urino snlts for flosion products.

A. Preparation of urino for colum.

i. Eveporate urine to dryness with $\mathrm{HNO}_{3}$ and muffle selts until they aro wh1te.

2. Dissolvo the mufflod salts in a minimum amount of $0.25 \mathrm{~K}^{2} \mathrm{HiO}_{3}$.

3. Centriruge of $i$ the snall insoluble rogiduo and wash. Plato tho rosicue for counting and add the wash to tho supernate.

4. The ombincd supernate and wash aro the fecd solution for tho fon colurn.

B. Opcration of the colunan.

5. The resin used is Dorex 50, part1clcs 100-150 mesh.

6. The colum is a glass tube of $65 \mathrm{~mm}$ diamoter. It has a plua of glass wool, and a rubber stoppor with an outlot tubo y1th a screw clanp for rogulating flow at the bottum. The top is fittod mith some arrangosent for continuous foed of dilute acid.

7. Place a column of rosin $10 \mathrm{cah}$ hid in tho glass tube. Th1s is best dono by pourlng wator into the colurm and adding the driod resin a small amount at a time. Each prrtion is allowed to sottle before tho noxt is addod.

-

8. Flom rato lisod 1s $10 \mathrm{ml}$ pür minute for fecd solution and $40 \mathrm{ml}$ por minute for elution.

9. Carc sully pour the ferd soluition linto tho colum and lot it mun through.

10. Allow 17 11tors of $0.25 \mathrm{~N} \mathrm{HNO}_{3}$ to elow thru tho column to rash out $\mathrm{Na}$ and $X$ oalty from tho urino. Discard thin solution.

11. Run 10 11tcrs of $4 \mathrm{~N} \mathrm{HNO}_{3}$ thrs the colurm. Ivuporate this solution to a small volumo, tranofer ts a counting plato, ovaporato to drmoss.

12. Flame the sample and count. 
Ion colum procedure for analya1a-of TTA-xaf Inateo-for-f1ss 10 mproducts.

A. Preparation of solution for coluran.

2. Save supornate and washings from $\mathrm{LaF}_{3}$ procipitation step (solution $\mathrm{A}$ ) and the $\mathrm{Al}\left(\mathrm{NO}_{3}\right)_{3}$ raffinate from the f1rst. TTA extreetion step (solution B) for analysis.

(a). Solution A

2. Evaporate combined wash and oupornate from LaF 3 preclpitation to drynoss. A precipltate will form durling evaporation.

3. Idd $10 \mathrm{ml}$ conc. $\mathrm{H}_{2} \mathrm{SO}_{4}$ to dried salts and again mavapote to dryness. Salt3 should be heated unt1l thoy aro compietoiy dry and no nore fumes come off.

4. Digost driod saits with $20 \mathrm{ml}$ of $0.25 \mathrm{~N} \mathrm{HNO}_{3}$ with heat.

5. Centringe off the insoluble residue and wash it twice with $0.25 \mathrm{~N}$ - $\mathrm{HNO}_{3}$.

6. Combline washings and superneto.

7. Plato the res1due and have 1t counted. It may contain part of the sr.

\section{(t). Solution $\bar{B}$}

8. Add $20 \mathrm{mg}$ of $S F$ and Ce carrior to solution $B$.

9. Add cone. (at least $12 \mathrm{~N}$ ) $\mathrm{HaOH}$ to $\mathrm{Al}\left(\mathrm{NO}_{3}\right)_{3}$ solution unt1l $\mathrm{Al}(\mathrm{Cll})_{3}$ forms and dissolves. Add $1 \mathrm{ml}\left(\mathrm{NH}_{4}\right)_{2} \mathrm{C}_{2} \mathrm{O}_{4}$ solution.

10. Centrifuge off precipitete and wash 1 t once with $12 \mathrm{~N} \mathrm{NaOH}$ and once With $\mathrm{H}_{2} \mathrm{O}$. Discard supernate and washings.

11. Dissolve procipitato in $5 \mathrm{mI} \mathrm{NN} \mathrm{KNO}_{3}$ and diluto to $0.25 \mathrm{H}$.

12. Combino n1th 0.2511 solution sttalned in stop 6 . Th1s is tho food Bolution for tho colunn.

B. Oporation of colurn. 


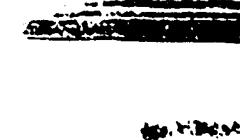

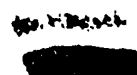

TiCLASSPIIED

Chemical analysis of raffinates from TTA analysis for flssion products with costum tor ton colum separation.

1. Evaporate urine to dryness w1th $\mathrm{HNO}_{3}$ and mufflo unt1l salts are white.

2. Dissolve mifrled salts in $2 \mathrm{NINO}_{3}$ - carry out standard TTA procedure saving supernate and washing from $\mathrm{IaF}_{3}$ precipitation for $\mathrm{Sr}$ and $\mathrm{Cs}$ aralysis.

3. Neutralize supernate from step $2 \pi 1$ th $\mathrm{NH}_{4} \mathrm{OH}$ unt1l it 1 approximately at a $\mathrm{pH}$ of 2 .

4. Add $40 \mathrm{mg} \mathrm{Sr}$ carrier and an excess of $(\mathrm{Na})_{2} \mathrm{SO}_{4}$.

5. Heat solution until $\mathrm{SrSO}_{4}$ preatpltates. Th1s can reguire a half hour or more. Add $\mathrm{H}_{2} \mathrm{O}$ if rolume gets top lor.

\%

6. Centrinige and wash procipltate once with dilute $\mathrm{Na}_{2} \mathrm{SO}_{4}$ and once with $\mathrm{H}_{2} \mathrm{O}$. Sdd mashings to supernate and save.

7. Transfer the precipitato to a counting plate and count for Sr.

8. Evaporate supernate to drgness to remove $\mathrm{NH}_{4}$ salts. D1sregard preclpitate whlch forms durling heating. Ihrfle at low hoat.

9. Digest dried salts with $0.25 \mathrm{~N}^{2} \mathrm{NO}_{3}$ and heat.

10. Contrifligo off insoiubio rosidue and waeb it twice mith 0.25 HiVo;. D1scard residue.

11. Pour combined supernate and washings thru an Ion exchange resin column for Cs analysis.

12. D1ssolvo $\mathrm{LaF}_{3}$ procipitate in $\mathrm{Al}\left(\mathrm{NO}_{3}\right)_{3}$ solution and shake with TTA solution for Pu analjsis, as in stendard TTE process.

13. Add concontrated $\mathrm{NaCH}$ (at loast $12 \mathrm{~N}$ ) to $\mathrm{Al}\left(\mathrm{NO}_{3}\right)_{3}$ rafflnate from f1rst TTA oxtractlon unt1l $\mathrm{Al}(\mathrm{OfI})_{3}$ has formod and dis3olved; add $1 \mathrm{ml}$ of saturated $\left(\mathrm{NH}_{4}\right)_{2} \mathrm{C}_{2} \mathrm{O}_{4}$ solution.

14. Centrifuge off precifitate and rash once with $12 \mathrm{~N}$ NaOls and once w1th $\mathrm{H}_{2} \mathrm{O}$. D1scard supernate and wash. 


\section{WVICSCIED}

HW- 18320

15. Transfer the precipltate to a colinting plate, dry, and count for raro oarths and otront1wir.

(1)

๑

(하)

(하

or.

웅

0

-

() 


\section{Rosin Preparation}

$\circ$

1. Soak required volume of Dorex 50 100-150 mesh in WN IICl for sereral hours. Stir occasionally.

2. Drain acld from resin and mash in distliled $\mathrm{H}_{2} \mathrm{O}$ to removo nil tracos of ac1d.

3. Dry resin on torel and store for future use.

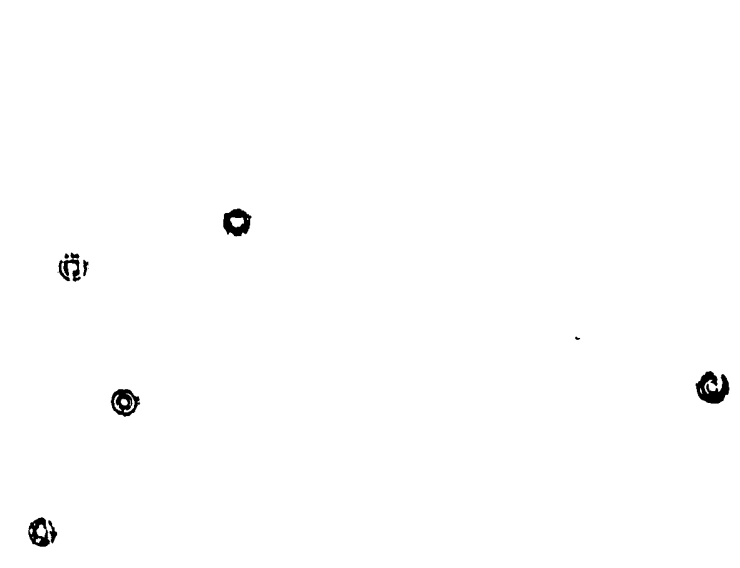

6

○

$\odot$

0

(2)

-

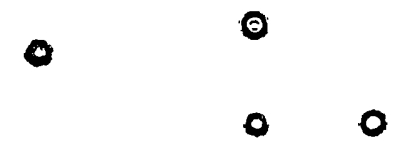

0

0

0

- 


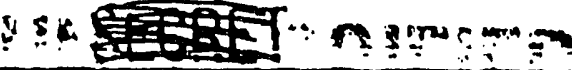

1:

FIG. I

DECLASSIFIED

FEED EQUIPMENT

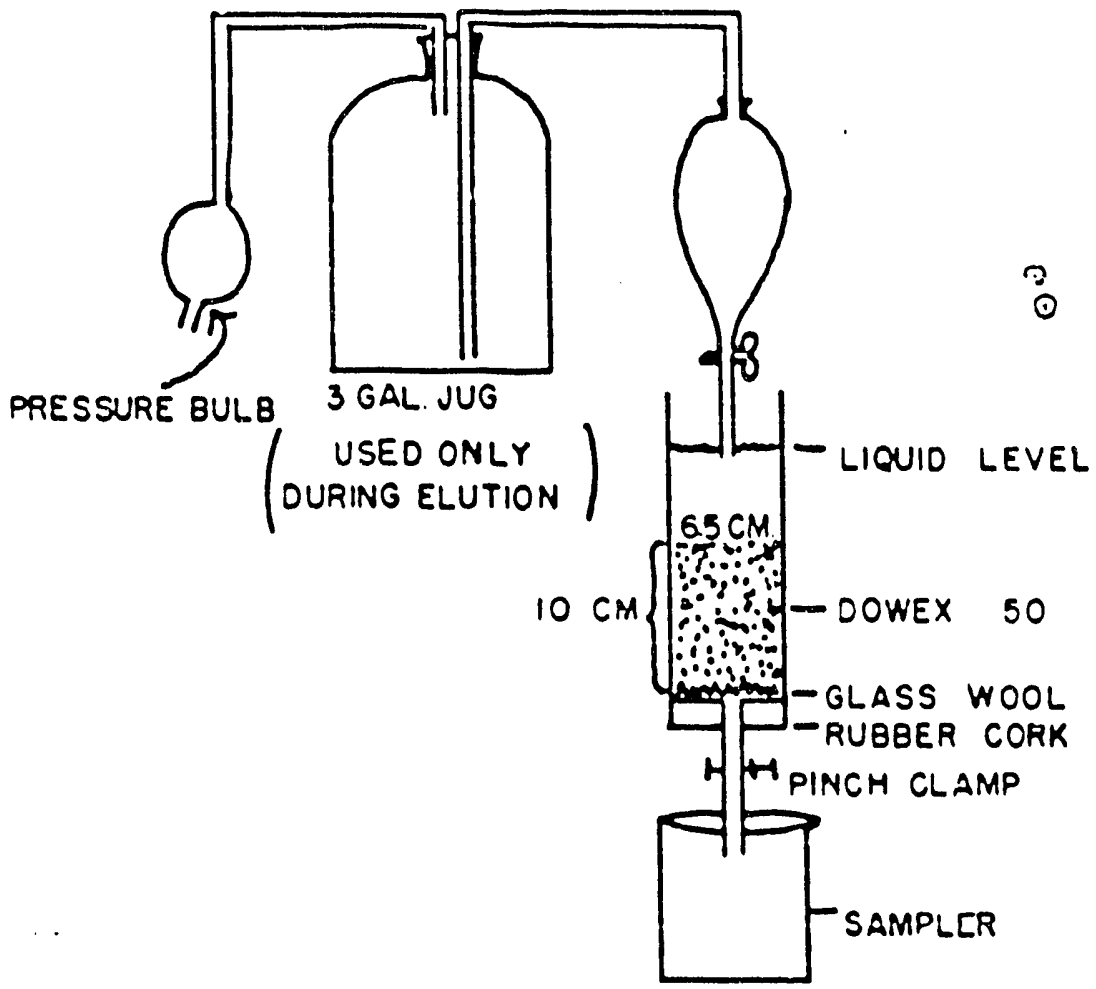




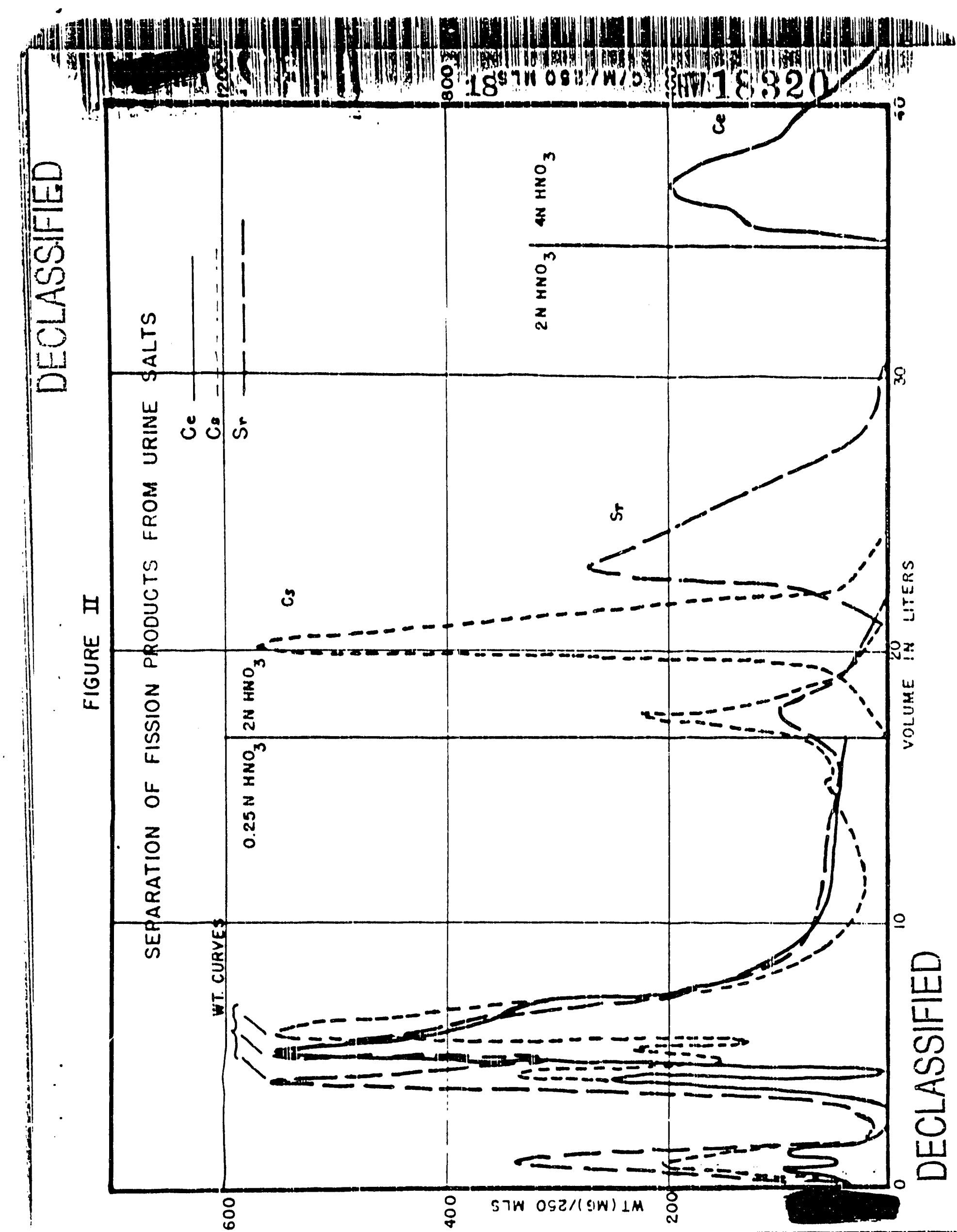




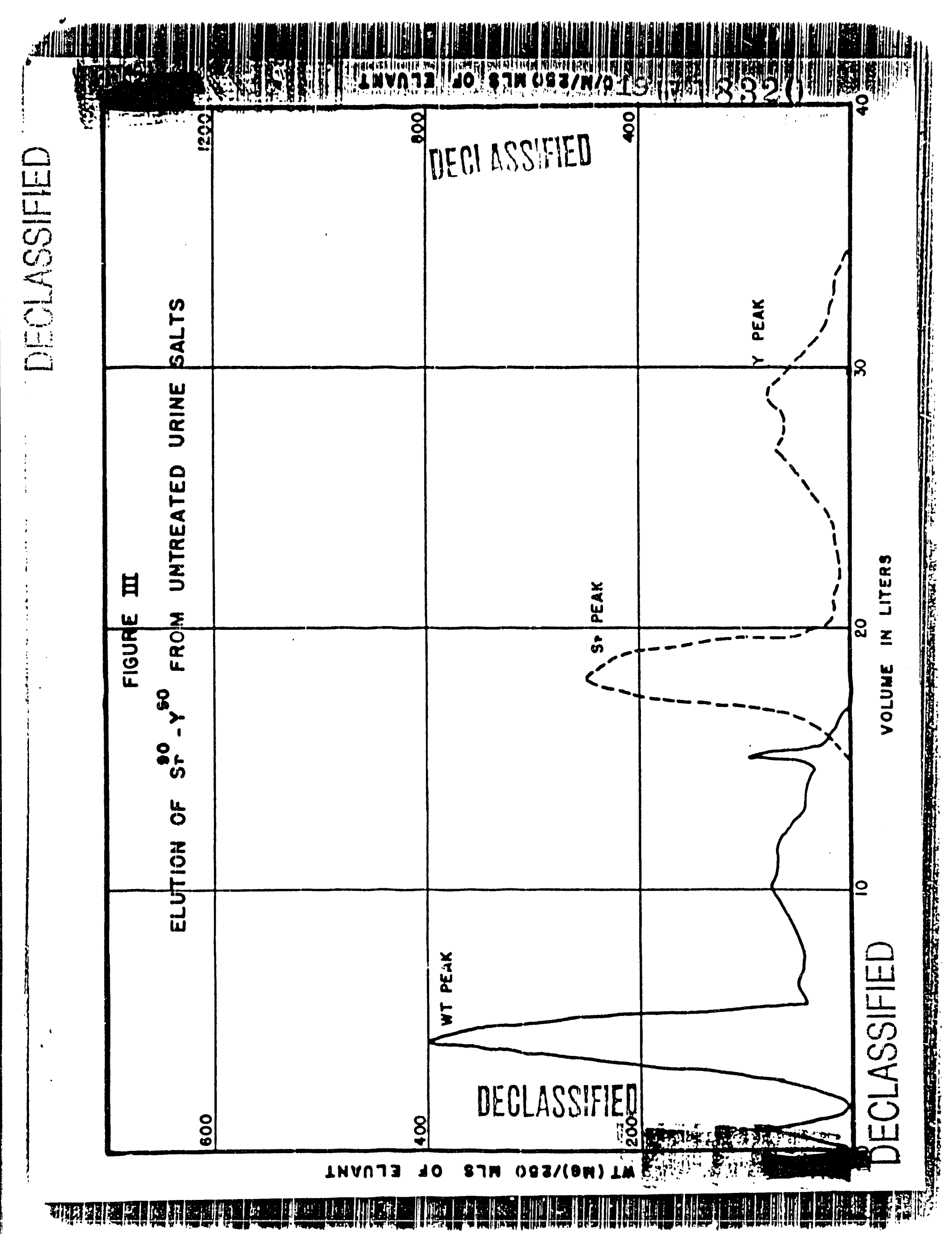




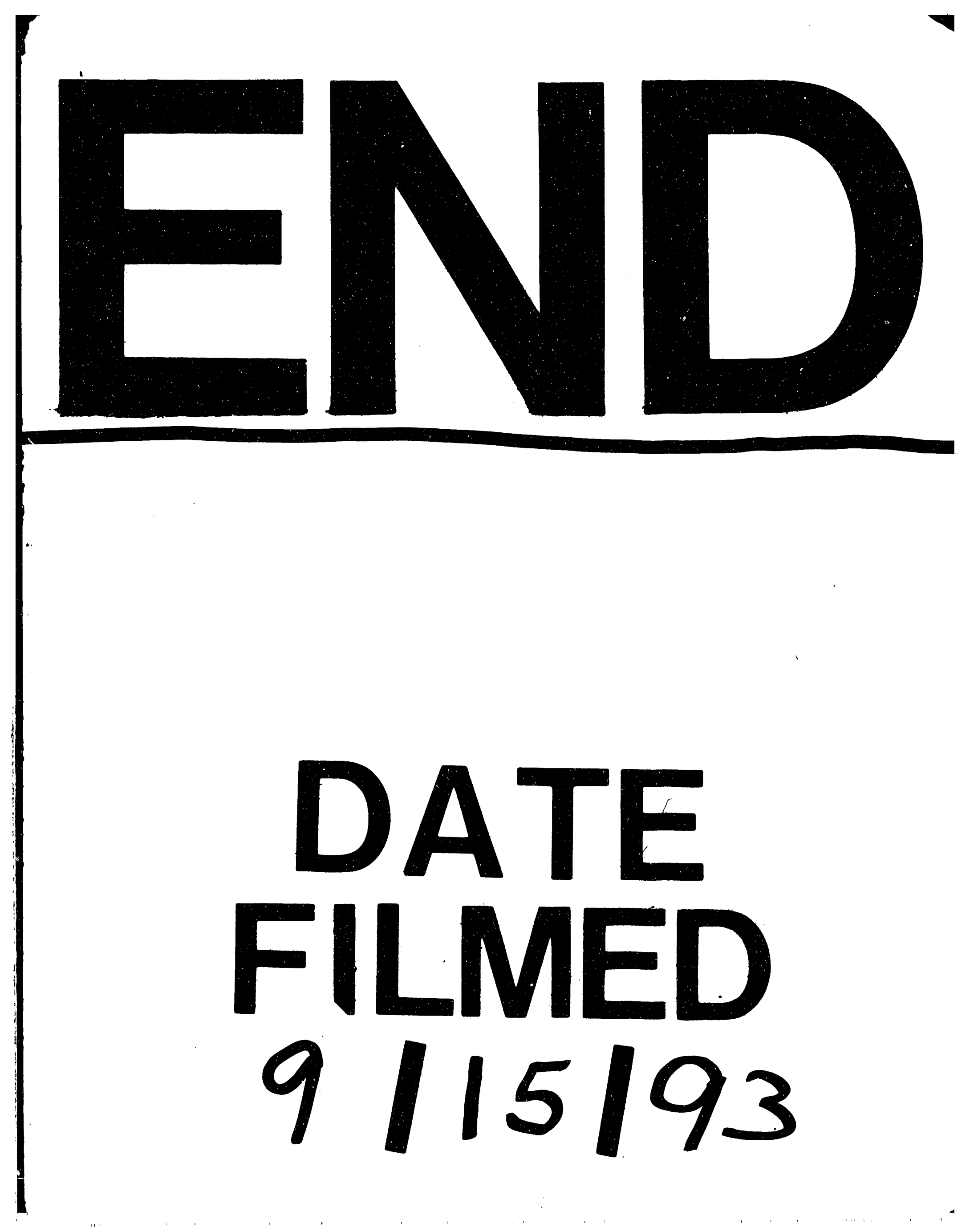


